\title{
Advanced Specialized Jordanian Libraries Services by Social Media Sites: Facebook
}

\author{
Khaldoon M. O. AL_Dwairi \\ Library and Information Department, Princess Alia University Collage, Al-Balqa Applied University
}

\begin{abstract}
This study dealt with Jordanian specialized libraries' presentation of their services through the social media website Facebook. The aims were to identify how Jordanian specialized libraries use social media sites, to describe their services and characteristics and to analyze comments on the advertisement boards of their social media websites. Data were collected from four libraries pages on Facebook. One of the most important findings of the study is that the four libraries had added the social media icon to their Internet pages. Three libraries specified their opening hours and holiday closing, Amman Chamber of Commerce library, the library of Zarqa branch of the Jordanian Engineers' Association and the library of the Shmaisani branch of the Jordanian Engineers' Association. All these libraries used Arabic on their Facebook pages.
\end{abstract}

Keywords: Specialized libraries-Jordan-social media sites- Facebook.

DOI: $10.7176 / \mathrm{IKM} / 9-3-01$

Publication date:March $31^{\text {st }} 2019$

\section{Introduction}

The impact of modern life on modern technology means that libraries, particularly specialized libraries, should use social media, which are widely used, to inform the community of the importance of library services. All libraries have developed a policy to use modern information technology to communicate effectively with their potential user community via social media such as Facebook and Twitter and other free access applications regarding less time and effort, exceeding the temporal and spatial boundaries to access the information. As libraries are no longer as they were in the past in terms of communication with beneficiaries, now the contact has to communicate with modern libraries. The main objective of libraries is to provide services to users and so libraries have found many ways to market their services to potential users in various geographical locations. The Internet made this easier and has contributed greatly to the spread of library services on various social media platforms, so those services become attractive to many people around the world and have several types to be discussed in the study.

\section{The Study Problem}

Libraries around the world seek to provide users with specific, valuable services. Contemporary libraries make extensive use of modern communication tools to achieve their goals. Since the advent of the Internet, libraries have used many ways to provide their services, both traditional and modern; the most important being social media platforms and it is this aspect of service provision that is analyzed in this study.

\subsection{Objectives}

1. To determine the extent to which Jordanian specialized libraries use social media sites.

2. To identify the services which Jordanian specialized libraries provide through social media sites?

3. To identify specialized libraries which are providing services through social media sites?

4. To analyze the content that Jordanian specialized libraries provide on social media sites.

\subsection{Research Questions}

1. Do Jordanian specialized libraries have pages on social media platforms?

2. Do Jordanian specialized libraries offer their services through social media platforms?

3. What is the general standard for the web pages of Jordanian specialized libraries? 


\subsection{Methods and Sample}

Quantitative method will be applied to collect and analyze the data, due this approach is considered the appropriate for our study. This research has chosen as a sample four Jordanian specialized libraries with Facebook pages.

\subsection{Terminology}

Specialized library: A library concerned with specialized intellectual products in a particular subject area or intellectual products related to a specific activity. Such libraries are usually found in government companies and institutions (AL-Maddaha 2011).

Social media site: A website that allows people from different parts of the world to communicate. These sites have reduced the importance of distance and made the world a small village. Each site has a host of characteristics that attracts users and recently, as the number of sites has increased, competition amongst them has become fierce (Mabreh 2017).

Facebook: One of the most popular social media sites. Created in 2004 by Mark Zuckerberg, Eduardo Saverin, Andrew McCollum, Dustin Moskovitz and Chris Hughes when they were students at Harvard University. It was originally created for Harvard university students and then extended to other universities and is now available to everyone (Mabreh 2017).

\section{Theoretical Framework}

Specialized libraries are a relatively recent phenomenon. They have existed since the 19th century to respond to the information needs associated with the industrial revolution and scientific discoveries, although some researchers trace their early beginnings to ancient civilizations. Some of the features now common to the specialized library are similar to those of old libraries.

This study attempts to describe the history of the specialized library in the ancient, middle and modern eras, to identify the evolution of the concept of the specialized library from mere receptacle of collections on specialized topics to provider of advanced information services. In the 1980 s specialized libraries merged with information centers, partly due to the development of information technology, and began to provide specialized information services to commercial, industrial and research bodies, ministries, professional associations, banks etc. (Badr 1998).

AL-Ameen \& Bashir (2017) dealt with social networks and their role in providing information services to beneficiaries in information institutions. The aims were to describe the information services provided to users through Facebook by Faisal Cultural Center in Khartoum, to describe how users of the Cultural Center used Facebook to meet their information needs, to highlight the role of information services provided through Facebook in building society's knowledge and to identify the challenges facing Faisal Cultural Center with respect to providing information services via Facebook.

A study of Obaid (2017) investigated the search engines, and how to search people on social media, then, he studied and analyzed their behavior with the purpose ofrebuilding of educational curricula and correcting the paths of some users in educational sectors. While, AL-Ustaz (2017) aimed to identify the social media networks used by the Ministry of Education in Kuwait and the role of these networks in training and certification of employees in the field of libraries and information, interviews were used to collect data and to explore how they can interact on their pages in social media sites. In other hand, Ahmed (2017) focused on his study how the persons are using social media and studied the knowledge and skills required from libraries in Arab countries.

Other study used the descriptive analysis approach as Al-Sawaf (2017) which investigates the role of Arab institutions that carries about libraries, which provide services on social media networks like Facebook and measure their quality, also he focused on how this platforms can attract new users to get benefits from their services.

Al-Kaddal (2017) aimed to introduce the concept of marketing to research on library service and to describe the role of social media sites in the promoting and marketing of library services. This study used descriptive and statistical methods to analyze questionnaire data. 
Yani (2018) analyzed the usage of social media by academic libraries in Indonesia; this study was applied on 51 Indonesian academic libraries. The study also examined the problems that academic libraries encounter in using social media as a means of communication. The results showed that academic libraries in Indonesia use social media to promote their services, facilities and collections. Facebook was the most widely used social media platform and the study also revealed that lack of time and human resources have become major problems in managing social media accounts.

Yeni \& Dinda (2018) examined the use of technical features to explore social media publications in six different academic libraries. The libraries published content on seven different social channels: Facebook, Flickr, Pinterest, Twitter, Instagram, Google + and YouTube (Harrison et al. 2017).

Khan \& Bhatti (2012) stated that the increasing use of social media makes it a challenge for libraries to maintain an up-to-date presence in the virtual environment. In the digital age libraries need social media tools that offer greater access to users, without time and space constraints. Social media also gives users more opportunity to interact with librarians without having to come to a building.

Table 1 shows the Jordanian specialized libraries, their websites and the addresses of their Facebook pages.

Table 1. The Jordanian Specialized Libraries

\begin{tabular}{|c|c|c|}
\hline & Website & Facebook address \\
\hline $\begin{array}{lr}\text { Library of } & \text { Zarqa } \\
\text { Chamber } & \text { of } \\
\text { Commerce } & \end{array}$ & $\begin{array}{l}\text { http://www.zarqachamber } \\
\text {.org/ }\end{array}$ & $\begin{array}{l}\text { https://web.facebook.com/pages/\%D8\%BA\%D8\%B1\% } \\
\text { D9\%81\%D8\%A9- } \\
\text { \%D8\%A7\%D9\%84\%D8\%AA\%D8\%AC\%D8\%A7\%D8 } \\
\% \text { \%1\%D8\%A9- } \\
\text { \%D8\%A7\%D9\%84\%D8\%B2\%D8\%B1\%D9\%82\%D8\% } \\
\text { A7\%D8\%A1/1536057079954737?rf=132430613598595 }\end{array}$ \\
\hline $\begin{array}{l}\text { Library of the } \\
\text { Amman Chamber } \\
\text { of Commerce }\end{array}$ & $\begin{array}{l}\text { http://www.ammanchamb } \\
\text { er.org.jo }\end{array}$ & https://web.facebook.com/AmmanChamberofCommerce \\
\hline $\begin{array}{l}\text { Library of the } \\
\text { Jordan Engineers' } \\
\text { Association-Zarqa } \\
\text { branch }\end{array}$ & http://www.jea.org.jo & $\begin{array}{l}\text { https://ar- } \\
\text { ar.facebook.com/pg/JEAzarqa/about/?ref=page_internal }\end{array}$ \\
\hline $\begin{array}{l}\text { Library of the } \\
\text { Jordan Engineers' } \\
\text { Association- } \\
\text { Shmeisani branch }\end{array}$ & http://www.jea.org.jo & https://web.facebook.com/Jordan.Engineers.Association \\
\hline
\end{tabular}

We can see from Table 2 that Facebook and Twitter are used by all libraries and just one library which is Jordanian Engineers Syndicate -Shmeisani has a YouTube channel.

Table 2. The use of Faebook, Twitter and YouTube in Libraries

\begin{tabular}{|l|c|c|c|}
\hline \multicolumn{1}{|c|}{ Library Name } & Twitter & Facebook & YouTube \\
\hline Library of Zarqa Chamber of Commerce & $\square$ & $\square$ & $\mathbf{x}$ \\
\hline Library of Amman Chamber of Commerce & $\square$ & $\square$ & $\mathbf{x}$ \\
\hline Library of the Jordan Engineers' Association - Zarqa branch & $\square$ & $\square$ & $\mathbf{x}$ \\
\hline $\begin{array}{l}\text { Library of the Jordan Engineers' Association - Shmeisani } \\
\text { branch }\end{array}$ & $\square$ & $\square$ & $\square$ \\
\hline
\end{tabular}

\section{Specialized library}

A specialized library is one established and managed by a business, private institution, government agency, nonprofit organization or special interest group to meet the information needs of staff working in the institution and others. Trustees are usually members of the Association of Specialized Libraries. Various definitions of the specialized library have been offered. These definitions include various characteristics, such as the size of the 
library, the specialization of its collections, its services and the identity of the supervising authority. These definitions encompass the libraries of commercial and industrial establishments, charitable organizations, government bodies and professional associations and may include specialized units in a university or public library. Specialized libraries are characterized by serving the supervising authority, for example an industrial or commercial establishment, specific ministry, government or private bank, news agency, advertising agency or other institution.

The names of specialized libraries vary according to their status in the organizational chart and according to their activities and services.

1. Technical Library.

2. Technical media Center.

3. Technical media Section.

4. Research Library.

5. Research Labs Library.

6. Technical Media Group.

7. Intellectual Production Research Section.

8. Research and Development Library.

9. Scientific Intelligence Center.

10. Arab Media Center (Aliwi\& Al-Maliki 2006).

\subsection{Functions of the Specialized Library}

According to Badr \& Kassem (1972) the typical functions of the specialized library are:

1) Creating and maintaining a collection of books, academic journals and other publications on a particular subject.

2) The acquisition of the references categorized by topics and specialized indexes.

3) Periodically publicizing disseminating printed information via special bulletins.

4) Lending books and facilitating the use of academic journals.

5) Organizing and indexing the internal and technicalreports.

6) Providing a reference service.

7) Compiling bibliographies and organizing reports.

8) Assisting in editing publications published by their institution.

9) Translating printed publications in foreign languages.

10) Various other services.

\subsection{Distinguishing Features of the Specialized Library}

1. Groups and collectibles: often confined to the subject of specialization and interests of the mother institution, which are represented at an advanced scientific and academic level.

2. Beneficiaries: typically employees of the institution and specialized, often with an advanced degree in the field of specialization. Their number is often limited.

3. Office materials: in specialized libraries books are often not the main source of information; specialized libraries typically place more emphasis on other more up-to-date or more specialized sources of information, such as academic journals, research, reports etc.

4. Technical procedures and services: usually more accurate and specialized. And trying to deliver appropriate information to the right person at the right time and the right place.

On the hand of dependency: specialized libraries are always linked to an institution, organization or association and tend to be smaller than other libraries (Al-Maddaha 2011). 


\section{Social Media}

In general the aim of social communication is to increase contacts by establishing relationships with others. After appearing of social media platforms, they become a method of establishing relationships between individuals. Hence social media platforms can be defined as sites that allow users to create personal accounts and to establish relationships with other users of the site; examples include Facebook, WhatsApp and YouTube (Mohammad 2017). In other hand, the appearance of social media made the communication operation more potential for the person to communicate with hundreds of other people about anything like products, companies or any information (Mangold \& Faulds 2009).

\subsection{The Most Popular Social Media Platforms}

Some social media platforms are very popular; they are visited by millions of people and used monthly. These sites include the following:

Facebook: has more than 2.3 billion users and is the largest social networking site. It was established in 2004 and is used by many companies.

Twitter: has more than 300 million users per month; users can publish 'tweets' with a maximum length of 140 characters. Companies use Twitter as it allows them to communicate with customers as well as publish their product news.

LinkedIn: has more than 400 million subscribers and is available in 24 languages. It was established in 2002 and is widely used by business people to connect with other companies or those looking for jobs.

Google Plus: has more than 400 million active users per month and was activated in 2011.

YouTube: the largest social networking site with more than 1 billion visitors a month. It is a video specialized and established in 2005 and later bought by Google for $\$ 1.65$ billion.

Instagram: a Facebook site with more than 400 million visitors that offers users many tools for editing photographs and videos.

Snapchat: an application that allows messaging through images. It was published in 2011; according to a report from statista.com in 2018, it has 186 million active users per day.

WhatsApp: an application for smart-phones, tablets and computers that allows users to create conversations with other users and send pictures, audio, video clips and document files; it has more than 1 billion users (Statista 2019; Mohammad 2017).

\subsection{The Most Famous Private Libraries in Jordan has Social Media Platforms}

Amman Chamber of Commerce. The Amman Chamber of Commerce was established in 1923 and it is a nonprofit organization of public interest, seeking to serve its members and operating under the provisions of provisional law No. 73 of 2003. It has played an important role in various fields of economic and social development in Jordan for more than half a century and has also played a leading role in trade promotion and economic development in general (Amman Chamber of Commerce, 2018).

Jordan Engineers' Association - Al-Shmeisani branch. The Jordanian Engineers' Association was established in 1948 and was granted a license in 1949. In 1958 it became the first General Authority of the Engineers Syndicate. Engineer Tawfiq Marar was the first president of the Engineers' Association, which has headquarters in Amman and in Jerusalem; the first law of the association was issued in 1972. The association has a legal personality and its affairs are managed by a council elected by the General Assembly in accordance with the provisions of the Association Law. It publishes an annual report documenting its achievements and a financial report. Each fund of the association issues its own annual report and presents administrative and financial reports to public bodies for approval (Jordan Engineers' Association, 2018).

Zarqa Chamber of Commerce. The Zarqa Chamber of Commerce is one of the oldest commercial chambers in the Kingdom. It was established in 1958 and it is the largest commercial chamber in the Kingdom after that of the capital, Amman. Its members are about eleven thousand merchants from various commercial sectors. The mission of the Chamber is to manage its relationships with the other commercial sectors, also to contribute on development of economic legislation that is commensurate with the interests of its members, to promote the 
business sector, to contribute to the formulation of and implementation of policies relevant to the commercial sector and to participate in the development of trade. One of its functions is create awareness and education by promoting the concept of a 'knowledge economy' based on the latest knowledge and experience, and it is considered a cornerstone of the Jordanian economy (Zarqa Chamber of Commerce, 2018).

Jordan Engineers' Association -Zarqa branch. The Jordan Engineers' Association was established in Zarqa in the mid-1970s as a committee. In the mid-1980s a committee was elected. The branch committee consists of seven members who serve a two-year term. Later on the law of the association was changed to be decentralized, the Branch Committee became the Branch Council and its term was extended to three years (Jordan Engineers' Association -Zarqa branch, 2018).

\subsection{The Applied Framework}

In this part the research discuss the history of Jordanian specialized libraries, and analyzing thecontent of the library pages on Facebook, and will explore the characteristics of the subscribers, at the end analyzing the process for updating social media pages.

The following table shows that the Library of Amman Chamber of Commerce had existed for 94 years before it had a website and had a presence on Facebook two years before it had its own website. The library of the Zarqa Chamber of Commerce had been established for 45 years when its website was created. The Internet had reached Jordan in 1994, meaning that it took nine years for this library to establish a website - a long time - and it did not have a presence on Facebook until 2014, 13 years after it introduced its website and 10 years after emergence of Facebook. The library of the Jordan Engineers' Association-Shmeisani branch, established its own website and Facebook page 69 years after the library opened. Finally, the library of the Jordan Engineers' Association-Zarqa branch established a website and Facebook page 42 years after the opening of the library.

Table 3. The Intervals Between Creation of A Library and Creation of a Web Page and its Facebook Page

\begin{tabular}{|l|c|c|c|}
\hline \multicolumn{1}{|c|}{ Library name } & $\begin{array}{c}\text { Date of library } \\
\text { creation }\end{array}$ & $\begin{array}{c}\text { The date of creating the } \\
\text { library's website }\end{array}$ & $\begin{array}{c}\text { Date of creating } \\
\text { the Facebook page } \\
\text { of the library }\end{array}$ \\
\hline $\begin{array}{l}\text { Amman Chamber of } \\
\text { Commerce }\end{array}$ & 1923 & 2017 & 2015 \\
\hline $\begin{array}{l}\text { Jordan Engineers' } \\
\text { Association-Shmeisani } \\
\text { branch }\end{array}$ & 1948 & 2017 & 2017 \\
\hline $\begin{array}{l}\text { Zarqa Chamber of } \\
\text { Commerce Engineers' }\end{array}$ & 1958 & 2003 & 2016 \\
\hline $\begin{array}{l}\text { Jordan } \\
\text { Association-Zarqa } \\
\text { branch }\end{array}$ & 1975 & 2017 & 2017 \\
\hline
\end{tabular}

In 2017 Jordan had 8.7 million Internet users (Internet World Statistics, 2018), representing 87.8\% of the population. The number of Facebook users was 5.3 million or $53.5 \%$ of the population and $95 \%$ of the population has a mobile phone (Ghazal, 2014). These statistics indicate that the majority of Jordanians are interacting and communicating electronically and are connected digitally with the outside world. 
Table 4.General Information on each Library

\begin{tabular}{|l|cc|l|l|l|}
\hline Library Name & $\begin{array}{l}\text { Library of } \\
\text { Amman } \\
\text { Chamber } \\
\text { Commerce }\end{array}$
\end{tabular}$\quad \begin{aligned} & \begin{array}{l}\text { Library of the } \\
\text { Jordan } \\
\text { Engineers' } \\
\text { Association } \\
\text { Shmeisani } \\
\text { branch }\end{array} \\
& \begin{array}{l}\text { General } \\
\text { information on the } \\
\text { page }\end{array}\end{aligned}$

We can see from this table that two of these libraries display their geographical location on Facebook; three libraries display their opening hours, which is important public information, and all the libraries have a link to their website on Facebook. The library of the Zarqa Chamber of Commerce was the only one without a 'Contact us' button on its website.

Many different previous studies discussed the content of web sites in general and social media in particular and its importance. Initially, Del Águila et al.(2013) present in their study that when the website has the ability to help consumers and offer them relevant information to obtain the products they want, with lower effort, it considered as efficiency, considering the previous the following table shows what each library has on its Facebook page:

- $\quad$ News and information about the Library.

- $\quad$ Announcements about library activities.

- $\quad$ Respond to queries.

Table 5. What each Library has on its Facebook Page

\begin{tabular}{|c|c|c|c|c|}
\hline Library Name & \multirow{2}{*}{$\begin{array}{ll}\text { Library } & \text { of } \\
\text { Amman } & \\
\text { Chamber } & \text { of } \\
\text { Commerce } & \end{array}$} & \multirow{2}{*}{$\begin{array}{l}\text { Library of the Jordan } \\
\text { Engineers' Association - } \\
\text { Shmeisani branch }\end{array}$} & \multirow{2}{*}{$\begin{array}{l}\text { Library of } \\
\text { Zarqa Chamber } \\
\text { of Commerce }\end{array}$} & \multirow{2}{*}{$\begin{array}{l}\text { Library of } \\
\text { the Jordan } \\
\text { Engineers' } \\
\text { Associatio } \\
\text { n - Zarqa } \\
\text { branch }\end{array}$} \\
\hline $\begin{array}{l}\text { Things on the } \\
\text { wall }\end{array}$ & & & & \\
\hline Library news & $\square$ & $\square$ & $\square$ & $\square$ \\
\hline $\begin{array}{l}\text { Announcements } \\
\text { about activities }\end{array}$ & $\square$ & $\square$ & $\square$ & $\square$ \\
\hline $\begin{array}{l}\text { Responses to } \\
\text { queries }\end{array}$ & $\mathbf{x}$ & $\square$ & $\mathbf{x}$ & $\mathbf{x}$ \\
\hline $\begin{array}{l}\text { Description of the } \\
\text { library's services }\end{array}$ & $\square$ & $\square$ & $\mathbf{x}$ & $\mathbf{x}$ \\
\hline $\begin{array}{ll}\text { Links } & \text { to } \\
\text { instructional } & \\
\text { videos } & \end{array}$ & $\mathbf{x}$ & $\mathbf{x}$ & $\mathbf{x}$ & $\mathbf{x}$ \\
\hline
\end{tabular}

It is clear from the table above that all libraries provide library news and announcements about their activities on their walls. Only two libraries describe the services they provide and only one, the library of the Jordan Engineers' Association -Shmeisani branch, shows responses to queries. None of the libraries provides links to instructional videos. It is clear that the library pages on Facebook do not offer all the services, in some libraries are available while in others are not. 
Table 6.The Numbers of Subscribers and Followers of the Libraries' pages on Facebook

\begin{tabular}{|l|c|c|}
\hline \multicolumn{1}{|c|}{ Library name } & Subscribers & Followers \\
\hline $\begin{array}{l}\text { Library of Amman Chamber of } \\
\text { Commerce }\end{array}$ & 48472 & 48344 \\
\hline $\begin{array}{l}\text { Library of the Jordan Engineers' } \\
\text { Association -Shmeisani branch }\end{array}$ & 183815 & 183246 \\
\hline $\begin{array}{l}\text { Library of Zarqa Chamber of } \\
\text { Commerce }\end{array}$ & 3759 & 10077 \\
\hline $\begin{array}{l}\text { Library of the Jordan Engineers' } \\
\text { Association -Zarqa branch }\end{array}$ & 10090 & 10077 \\
\hline
\end{tabular}

This table shows that the library of the Zarqa Chamber of Commerce has fewest subscribers $(n=3759)$ and the library of the Jordan Engineers' Association -Shmeisani branch the most. The library of the Amman Chamber of Commerce has the most followers and the library of the Zarqa Chamber of Commerce the fewest.

Table 7.The Dates for Libraries when Updating their Pages on Facebook

\begin{tabular}{|l|c|c|}
\hline \multicolumn{1}{|c|}{ Library Name } & Most recent update & The updated date \\
\hline $\begin{array}{l}\text { Library of Amman Chamber of } \\
\text { Commerce }\end{array}$ & June 17, 2018 & June 3, 2018 \\
\hline $\begin{array}{l}\text { Library of Zarqa Chamber of } \\
\text { Commerce }\end{array}$ & June 24, 2018 & June 23, 2018 \\
\hline $\begin{array}{l}\text { Library of the Jordan Engineers' } \\
\text { Association -Zarqa branch }\end{array}$ & June 20, 2018 & June 14, 2018 \\
\hline $\begin{array}{l}\text { Library of the Jordan Engineers' } \\
\text { Association -Shmeisani branch }\end{array}$ & June 24,2018 & June 24, 2018 \\
\hline
\end{tabular}

The above table shows that all libraries made their two most recent updates to their Facebook pages in June 2018.

\section{Conclusion}

To conclude, this study found the longest gap between the establishment of a library and its website is that of the library of the Zarqa Chamber of Commerce (1923-2017). In other side, three of the libraries created their website and Facebook pages at the same time, those of the Amman Chamber of Commerce, Jordan Engineers' Association-Shmeisani branch and Jordan Engineers' Association-Zarqa branch.

In terms of links all libraries in this study mentioned above have a link to their own website on Facebook. Moreover, the Jordan Engineers' Association library is the only that responds to inquiries, regarding to notice board the percentage of news is rising.

\section{Recommendations and Limitations}

We recommend that the libraries should offer clear information about libraries' roles and its services to avoid repeated questions, publish regularly library news in Facebook pages so users and potential users are always informed. Furthermore, posting pictures of training courses, activities, workshops and videos links encourage visitors to be engaged. Regards to study limitations, not all advanced specialized Jordanian libraries are covered in this study; future research should expand the sample. This article study the libraries in two provinces (Amman and Zarqa), the other studies could investigate other libraries in deferent cities in Jordan.

\section{References}

Ahmed, O.S. (2017). "The basics of using social networks in Arab Libraries", The 28th Conference of the Arab Union of Libraries and Information: Social Networks and their Impact on Information Institutions in 
the Arab World, Cairo: The Arab Federation for Libraries and Information.

AL-Ameen, S.A., \& Bashir, A.S. (2017). "Which dealt with social networks and their role in promoting information services to beneficiaries in Al-Faisal Cultural Center: Khartoum?", The 28th Conference of the Arab Union of Libraries and Information: Social Networks and their Impact on Information Institutions in the Arab World, Cairo: The Arab Federation for Libraries and Information.

Aliwi, M.,\& Al-Maliki, M. (2006). “The quality libraries (national - university - specialized - general school)",Amman: Al-Warraq Establishment for Publishing and Distribution.

Al-Kaddal, H.A.A. (2017). "The use of social networks for the marketing of information services", The 28th Conference of the Arab Union of Libraries and Information: Social Networks and their Impact on Information Institutions in the Arab World,Cairo: The Arab Federation for Libraries and Information.

AL-Maddaha, A. N. (2011). "Types of libraries”, Amman: Dar Al-Maysara for Publishing and Distribution.

Al-Sawaf, N.A. (2017). "Facebook pages of Arab professional institutions for libraries and information: An Analytical Study", The 28th Conference of the Arab Union of Libraries and Information: Social Networks and their Impact on Information Institutions in the Arab World,Cairo: The Arab Federation for Libraries and Information.

AL-Ustaz, S. (2017). "The Social Network of the Ministry of Education and its role in training the qualification of workers in the field of libraries and information", The 28th Conference of the Arab Union of Libraries and Information: Social Networks and their Impact on Information Institutions in the Arab World,Cairo: The Arab Federation for Libraries and Information.

Amman Chamber of Commerce. (2018). "Brief history of the Amman Chamber of Commerce", Retrieved from http://www.ammanchamber.org/node/?id=6\&lang=ar\%D9\%90.

Badr, A. (1998). "Specialized libraries and information centers in the management and organization of information services", Cairo: Academic Library.

Badr, A., \& Kassem, H. (1972). "Specialized libraries: management, organization and services”, Kuwait: The Publications Agency.

Del Águila O., \& A., Padilla-Meléndez, A., \& Al-Dweeri, R.M. (2013). "Inputs y Outputs en la calidad de los servicios electrónicos: revisión de la literatura y propuesta de un modelo de relaciones". Revista Innovar. 23(49), 67-82.

Ghazal, M. (2014). (February 26). "95\% of Jordanians own mobiles; $47 \%$ use the Internet",Jordan Times. Retrieved from www.jordantimes.com/news/local/95-jordanians-own-mobiles-47-use-internet.

Harrison, A., \& Burress,R., \& VelasquezS., \& Schreiner, L. (2017). "Social media use in academic libraries: A phenomenological study. Journal of Academic Librarianship. 43(3), 248-256.

Internet World Statistics. (2018). Usage and population statistics: Jordan. Retrieved from www.internetworldstats.com/stats5.htm. Last accessed February 11, 2018.

Jordan Engineers' Association-Zarqa $\quad$ branch.(2018), Retrieved from http://www.jea.org.jo/branches/route.php?src=section_menu\&id=306\&sub_id=5030\&M1Id=9.

Jordan Engineers' Association. (2018). Retrieved fromhttp://www.jea.org.jo/portal/our-assosication. Last accessed August 1, 2018.

Khan, S.A., \& Bhatti, R. (2012). "Application of social media in marketing of library and information services: A case study from Pakistan”.Webology.9(1). http://www.webology.org/2012/v9n1/a93.html.

Mabreh, T. (2017). "The most important social networking sites", Retrieved from http://mawdoo3.com.Last accessed July 12, 2017.

Mangold, W. G., \& Faulds, D. J. (2009). "Social media: The new hybrid element of the promotion mix". Business Horizons.52(4), 357-365.

Mohammad, M. (2017). "A research about social networking sites”, Retrieved fromhttps://mawdoo3.com/.Last accessed August 1, 2018.

Obaid, A. (2017). "The development of a personal search engine on social networks: Facebook Model: Egypt", The 28th Conference of the Arab Union of Libraries and Information: Social Networks and their Impact on Information Institutions in the Arab World, Cairo: The Arab Federation for Libraries and Information.

Statista (2019). "The Statista Portal”, Retrieved from https://www.statista.com/. Last accessed February 12, 2019. 
Yeni, B.R., \& Dinda, A.P. (2018). "Social media application in Indonesian academic libraries".Webology.15(1).http://www.webology.org/2018/v15n1/a162.pdf.

Zarqa Chamber of Commerce. (2018). Retrieved from www.zarqachamber.org/index.php?option=com content\&view=article\&id=20\&Itemi $d=576 \& l a n g=a r$. Last accessed May 25, 2018. 